SECTION 19. Management. Marketing. Public administration.

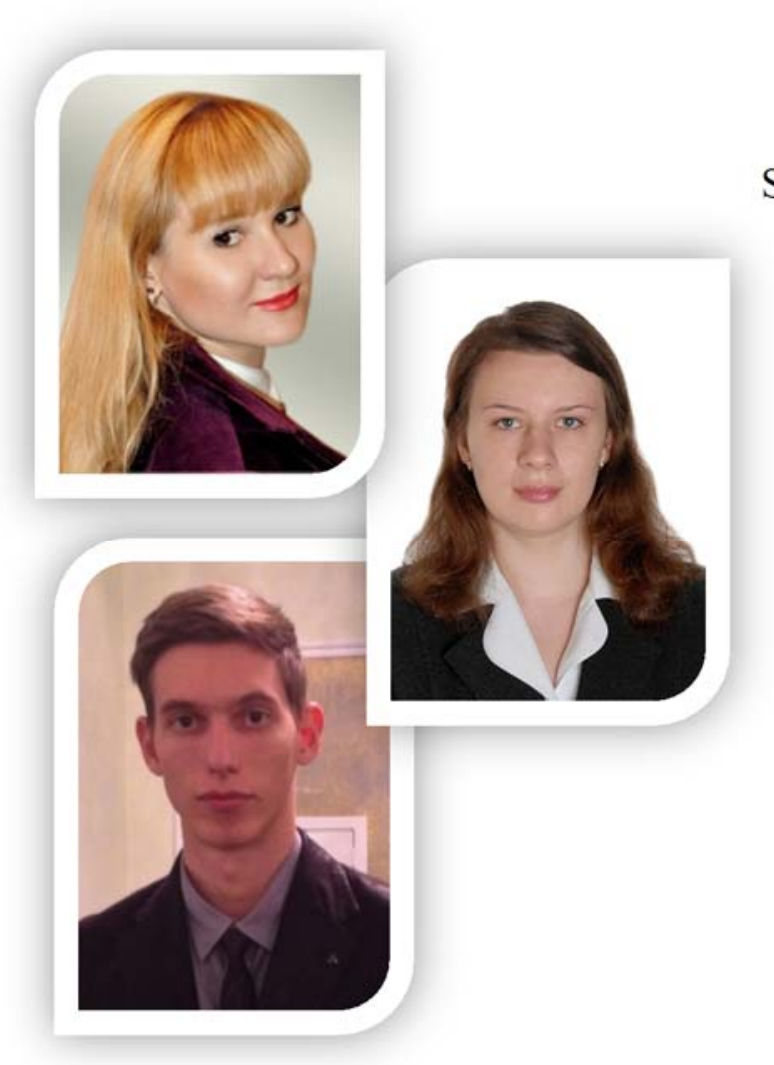

Tatiana Vitalievna Butova the Deputy Dean of the faculty of Public and municipal administration, Candidate of Economic Science, Docent, the Financial University under the Government of the Russian Federation tvbutova@mail.ru

Marina Konstantinovna Krivtsova the third year student, bachelor, the Chairman of Scientific Student Society of the faculty of Public and municipal administration at the Financial University under the Government of the Russian

Federation marinstar@bk.ru

Vladislav Pavlovich Tolmachev the third year student, bachelor, the member of Scientific Student Society of the faculty of Public and municipal administration at the Financial University under the Government of the Russian

Federation tolmachev.vp@yandex.ru

\title{
THE FORMATION OF OFFERS REGARDING THE MODIFICATION OF REGULATIONS FOR INTRODUCING THE EFFECTIVE SYSTEM OF PUBLIC ADMINISTRATION OF FORESTRY
}

Abstract: In this work offers regarding the modification of the current legislation for introducing the effective system of public administration of forestry are touched upon. The list of the regulations which are necessary for implementing these developed offers is provided as well. efficiency

Key words: forestry, public administration, regulations, Forest code, management УДК 351

\section{ФОРМИРОВАНИЕ ПРЕДЛОЖЕНИЙ ПО ВНЕСЕНИЮ ИЗМЕНЕНИЙ В НОРМАТИВНЫЕ ПРАВОВЫЕ АКТЫ В ЦЕЛЯХ ВНЕДРЕНИЯ ЭФФЕКТИВНОЙ СИСТЕМЫ ГОСУДАРСТВЕННОГО УПРАВЛЕНИЯ ЛЕСНЫМ ХОЗЯЙСТВОМ}

Аннотация: В данной работе освещзены предложения по внесению изменений в действующее законодательство для внедрения эффективной системь государственного управления лесным хозяйством. Приводится перечень нормативных правовых актов, необходимых для реализации разработанных предложений.

Ключевые слова: лесное хозяйство, государственное управление, нормативные правовые акты, Лесной кодекс, эффективность управления

Реализация предлагаемых изменений в структуре государственного управления лесным хозяйством Российской Федерации потребует внесения ряда изменения в 
нормативные правовые акты Российской Федерации, регулирующие данную сферу общественных отношений. [2, с. 18]

Ряд изменений должны быть внесены в Лесной кодекс Российской Федерации, в первую очередь:

- в части изменения роил государственных учреждений в системе государственного управления лесным хозяйством Российской Федерации;

- в части передачи полномочий по осуществлению государственного лесного контроля и надзора и государственного пожарного надзора в лесах Российской Федерации;

- в части выделения самостоятельного функционала по организации проведения мониторинга состояния лесного хозяйства Российской Федерации и его передачи негосударственной организации.

Реализация каждого из указанных предложений потребует принятия ряда подзаконных актов, а именно:

- о внесении изменений в Положение о Федеральном агентстве лесного хозяйства;

- об утверждении порядка передачи полномочий по мониторингу состояния лесного хозяйства Российской Федерации негосударственной организации;

- o реализации полномочий государственных учреждений в сфере хозяйственного управления лесным хозяйством Российской Федерации.

Полный перечень возможных проектов нормативных правовых актов, необходимых для реализации предложений, разработанных в рамках настоящей дипломной работы, представлен в таблице 1.

Таблица 1

\section{Перечень нормативных правовых актов, необходимых для реализации разработанных предложений}

\begin{tabular}{|c|c|c|c|}
\hline $\begin{array}{l}\text { № } \\
\text { ПI/II }\end{array}$ & $\begin{array}{c}\text { Тип } \\
\text { нормативного } \\
\text { правового акта }\end{array}$ & $\begin{array}{c}\text { Краткое } \\
\text { наименование }\end{array}$ & Содержание \\
\hline 1 & $\begin{array}{l}\text { Федеральный } \\
\text { закон }\end{array}$ & $\begin{array}{l}\text { O внесении } \\
\text { изменений } \\
\text { Лесной кодекс } \\
\text { Российской } \\
\text { Федерации }\end{array}$ & $\begin{array}{l}\text { Внесение изменений в Лесной кодекс } \\
\text { Российской Федерации, направленных на: } \\
\text { - передачу полномочий по реализации } \\
\text { государственного лесного контроля и } \\
\text { надзора на уровень Российской Федерации; } \\
\text { - изменение возможной роли } \\
\text { государственных учреждений в системе } \\
\text { управления лесным хозяйством Российской } \\
\text { Федерации; } \\
\text { - разделение полномочий по управлению и } \\
\text { контролю за лесным хозяйством и по } \\
\text { организации мониторинга состояния } \\
\text { лесного хозяйства Российской Федерации } \\
\text { [5, с. 82] }\end{array}$ \\
\hline 2 & $\begin{array}{l}\text { Постановление } \\
\text { Правительства } \\
\text { Российской } \\
\text { Федерации }\end{array}$ & $\begin{array}{lr}\text { О внесении } \\
\text { изменений } \\
\text { Положение } \\
\text { Федеральном } \\
\text { агентстве } \\
\text { лесного } \\
\end{array}$ & 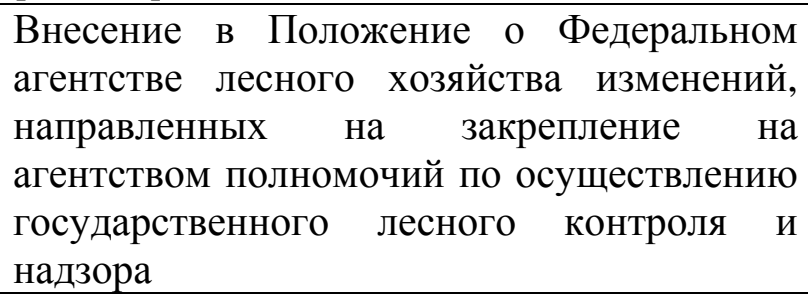 \\
\hline
\end{tabular}


ISPC Computer technologies in science, 30.04.2014

\begin{tabular}{|c|c|c|c|}
\hline & & хозяйства & \\
\hline 3 & $\begin{array}{l}\text { Постановление } \\
\text { Правительства } \\
\text { Российской } \\
\text { Федерации }\end{array}$ & $\begin{array}{l}\text { Положение об } \\
\text { организации } \\
\text { управления } \\
\text { лесным } \\
\text { хозяйством на } \\
\text { базе } \\
\text { государственных } \\
\text { учреждений }\end{array}$ & 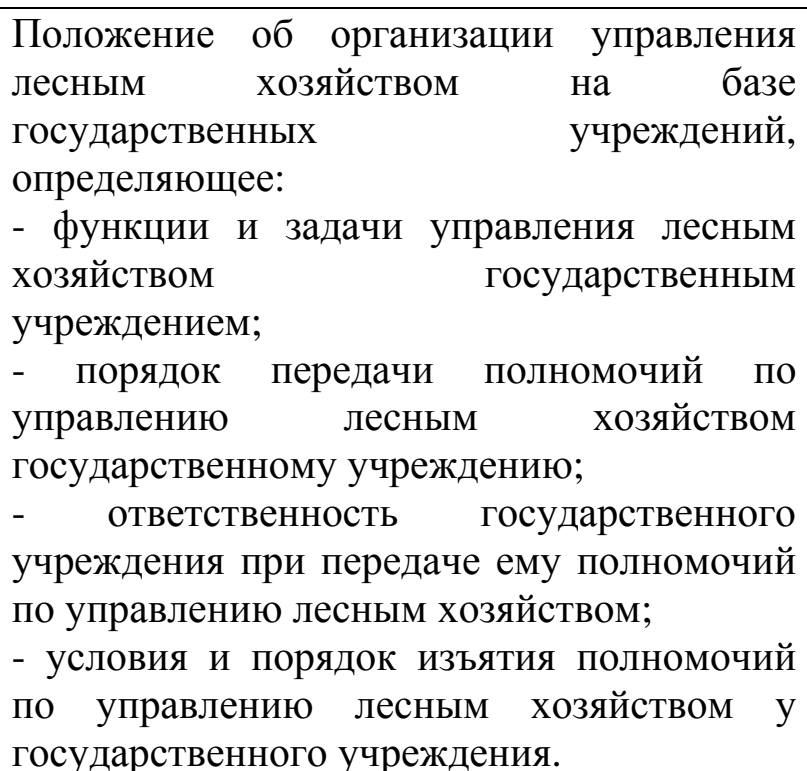 \\
\hline 4 & $\begin{array}{l}\text { Постановление } \\
\text { Правительства } \\
\text { Российской } \\
\text { Федерации }\end{array}$ & $\begin{array}{l}\text { Об определении } \\
\text { организации, } \\
\text { осуществляющий } \\
\text { мониторинг } \\
\text { состояния } \\
\text { лесного } \\
\text { хозяйства } \\
\text { Российской } \\
\text { Федерации }\end{array}$ & $\begin{array}{l}\text { Постановлением Правительства } \\
\text { Российской Федерации необходимо } \\
\text { определить: } \\
\text { - порядок и принципы выбора организации } \\
\text { для проведения мониторинга состояния } \\
\text { лесного хозяйства Российской Федерации; } \\
\text { - принципы и источники финансирования } \\
\text { деятельности организации по проведению } \\
\text { мониторинга состояния лесного хозяйства } \\
\text { Российской Федерации; } \\
\text { - ответственность организации при работе с } \\
\text { данными о состоянии лесного хозяйства } \\
\text { Российской Федерации. }\end{array}$ \\
\hline 5 & $\begin{array}{l}\text { Распоряжение } \\
\text { Правительства } \\
\text { Российской } \\
\text { Федерации }\end{array}$ & $\begin{array}{l}\text { Об определении } \\
\text { организации, } \\
\text { ответственной за } \\
\text { проведение } \\
\text { мониторинга } \\
\text { состояния } \\
\text { лесного } \\
\text { хозяйства } \\
\text { Российской } \\
\text { Федерации }\end{array}$ & $\begin{array}{l}\text { Распоряжением Правительства Российской } \\
\text { Федерации должна быть определена } \\
\text { конкретная организация, ответственная за } \\
\text { организацию проведение мониторинга } \\
\text { состояния лесного хозяйства Российской } \\
\text { Федерации. }\end{array}$ \\
\hline
\end{tabular}

\section{References:}

1. Арбузова Т.В. Совершенствование организационной структуры управления лесным хозяйством // Известия Российского государственного педагогического университета им. А.И. Герцена. 2008. № 73-1.

2. Артамонова В.О. Государственное управление в сфере охраны и защиты лесов // Актуальные проблемы российского права, 2013, № 8.

3. Атаманчук Г. В. Управление: сущность, ценность, эффективность. - М.: Академический проект, 2006. 
4. Гиряев М.Д., Кеникстул В.И., Глебов В.П. Совершенствовать систему управления лесным хозяйством // АПК: Экономика, управление. 2009. № 5.

5. Клейнхоф И.А. Реформирование системы управления лесами и лесным хозяйством через призму кризисных ситуаций // Национальные интересы: приоритеты и безопасность. 2011. № 5.

6. Оленина Т.Ю. Правовые аспекты лесного планирования как административноправовой формы государственного регулирования лесных правоотношений // Административное право и процесс, 2013, № 7.

7. Паршута В.В. Государственное управление лесами // Административное право и процесс, 2011, № 3

8. Рагулина Ю.В. Инновационный потенциал организации как фактор конкурентоспособности. // Материалы научно-практической конференции «Проблемы сохранения экономического и экологического баланса в России во взаимодействии с тенденциями поступательного развития экономики». М.: МГОУ, 2011.

9. Седов А.А. Функции управления лесным хозяйством // Актуальные проблемы российского права. 2007. № 1.

10. Якунин В.И. Теоретические аспекты проблемы эффективности государственного управления // Журнал «Власть», №8, 2006. 